\title{
New species and records of Phreodrilidae (Annelida: Clitellata) from Western Australia
}

\author{
Adrian M. Pinder \\ Department of Conservation and Land Management, P.O. Box 51, Wanneroo, 6946 Western Australia. \\ Email adrianp@calm.wa.gov.au
}

\begin{abstract}
Two new species of Phreodrilidae are described from habitats and regions of Western Australia from which the family has not previously been recorded. Phreodrilus peniculus sp. nov., the first phreodrilid to be described from north-western Australia, is characterised by a very short pseudopenis terminating in a small papilla at the apex of a long invagination of the body wall. This and other Phreodrilus with coiled pseudopenes are shown to have the pseudopenes and sometimes part of the atria ciliated. Astacopsidrilus edwardi sp. nov., which inhabits temporary seepages on granite outcrops of the inland south-west, has a swelling on the spermathecal ducts and often has replicated spermathecal chaetae. Additional records are provided for some previously recorded species.
\end{abstract}

Keywords: Phreodrilidae, oligochaetes, springs, Pilbara region, granite outcrops, new species

\section{INTRODUCTION}

Until recently, the only phreodrilid recorded from Western Australia was Astacopsidrilus novus Jackson, 1931, which is still known only from Lesmurdie Falls near Perth (Jackson, 1931). Pinder and Brinkhurst (1997) listed eight additional species, including three original species descriptions, notes on three undescribed species and records of two species also known from south-eastern Australia. These species are all from the near-coastal regions of south-western Australia, mostly from the high rainfall Warren bioregion. The present paper describes two additional species: one known only from temporary seepages on granite outcrops in the central wheatbelt and goldfields and one from springs in the Pilbara region. Additional records of some previously described species are also provided.

\section{METHODS}

Specimens of $P$. peniculus were collected using a $D$ frame sweep net and specimens removed from the sample in the field (Halse et al., in press), while $A$. edwardi were hand-picked from beneath moss beds on granite outcrops. Specimens of both species were killed and preserved in $70 \%$ ethanol. Examined material is deposited with the Western Australian Museum (WAM), or retained by the author (AP collection).

\section{SYSTEMATICS}

Phreodrilus peniculus sp. nov.

Figures $1 \mathrm{~A}, \mathrm{C}$ and $2 \mathrm{~A}$

\section{Material examined}

\section{Holotype}

Flowing water in reach with predominantly fine sediments, downstream of Warrie Springs in upper tributary of Shaw River, $22^{\circ} 15^{\prime} 36^{\prime \prime S} 119^{\circ} 42^{\prime} 21$ "E, 8 Sep 2001, coll. S. Halse, J. Cocking and M. Scanlon, dissected on slide (WAM V 4205).

\section{Paratypes}

Spring water trickling through cobble/pebble substrate and flowing into Cangan Pool on Cockerega Creek, a tributary of Yule River, site $\mathrm{PHCO2}$ of WA Monitoring River Health Initiative, $21^{\circ} 41^{\prime} 50^{\prime \prime} \mathrm{S} 118^{\circ} 37^{\prime} 43^{\prime \prime} \mathrm{E}, 14$ May 1995, coll. P. Papas, 1 dissected and 1 whole-mounted on slide (WAM V 4206 and V4207) and 5 Oct 1995, coll. M. Smith, 1 dissected on 2 slides (WAM V 4209). Bedrock/ cobble/pebble substrate at Palm Springs, Fortescue River, 2151'31"S 116030'57"E, 6 Sep 2001, coll. S. Halse, J. Cocking and M. Scanlon, 1 dissected on slide (AP collection).

Conductivity at the collection sites ranged from 655 to $2580 \mu \mathrm{S} / \mathrm{cm}$ and $\mathrm{pH}$ ranged from 7.72 to 8.06 .

\section{Etymology}

Peniculus: latin diminutive of penis, referring to the rudimentary penial apparatus.

\section{Description}

Length of preserved incomplete specimens: holotype $>11 \mathrm{~mm}$, other specimens up to $10 \mathrm{~mm}$. Width of $X 0.48-0.52 \mathrm{~mm}$. Prostomium bluntly rounded. Pharynx in II and III, oesophagus in IV - 
IX, widening to intestine in $\mathrm{X}$. Pharyngeal glands on pharynx and septa $2 / 3-6 / 7$. Ventral chaetae paired from II, $80-120 \mu \mathrm{m}$ long, largest in first few segments, one chaeta of each pair bifid with small upper teeth and a distal nodulus, the other narrower, without a nodulus and simple pointed (Figure 1A). Ventral chaetae absent on XII, present but not modified on XIII. Dorsal chaetae 1 or 2 (rarely 3) thin hairs per bundle from III, 150-325 $\mu \mathrm{m}$ long, paired support chaetae present.

Genitalia paired. Testes and ovaries in XI and XII respectively. Clitellum from $1 / 2$ XII to $13 / 14$. Male funnels cup-shaped to tubular, narrow ciliated vasa deferentia penetrating the atrial muscle layer medially (Figure 2A) before travelling within the muscle layer and joining the atrial lumen at the start of the pseudopenis. Atria short and broad (360 x 75 $-450 \times 112 \mu \mathrm{m})$, not folded, with thin muscle layer. Atria with tall glandular lining cells and a lumen that is narrow and apparently unciliated for most of its length but which becomes broader and ciliated just before joining the vasa deferentia at start of small protrusible pseudopenes. Pseudopenes small (35 - $45 \mu \mathrm{m}$ long), each lying within a muscular sac and consisting of tall non-glandular lining cells with cilia projecting into the lumen (Figure $1 \mathrm{C}$ ), terminating in a small papilla (essentially a rudimentary pendant penis) at the apex of a long $(175-220 \mu \mathrm{m})$ invagination of the body wall. Ventro-lateral male pores half way between $11 / 12$ and $12 / 13$. Small spermathecal vestibules with dorso-lateral pores at $12 / 13$, leading to ampullae which extends over 1 or more segments, starting from XIV or more posteriorly (XIX - XXI in the holotype). Ampullae with loose sperm. Female funnels leading to ventro-lateral pores at 12/13.

\section{Remarks}

The two genera with dorso-lateral spermathecal pores (subfamily Phreodrilinae of Brinkhurst [1991]) are normally distinguished from one another by the presence of either pendant penes (Antarctodrilus) or pseudopenes (Phreodrilus). Presence of pendant penes would seem to be the plesiomorphic state and are thus assumed to have been lost (or at least reduced) in Phreodrilus species (Brinkhurst, 1991). In the new species, the papilla on which the male duct terminates is essentially a small pendant penis but the presence of a pseudopenis indicates that this species should be considered a member of the genus Phreodrilus. Phreodrilus beddardi Benham has a well developed convoluted pseudopenis which terminates in a similar papilla, albeit at the apex of a much shorter ectal invagination than that of the new species. The pseudopenes of $P$. peniculus are rudimentary compared to its congeners and appear only sufficiently well developed to provide enough flexibility for the ectal invagination to evert and thus protrude the papilla from the male pores (as on specimen WAM V 4207).

Ciliation within the atrium has not been recorded for other phreodrilids so the finding of cilia in a short portion of the atrial lumen (but entad of the vas/pseudopenial union), as well as in the pseudopenis, prompted re-examination of other species, particularly of the genus Phreodrilus. Beddard (1891) described the highly coiled pseudopenis of Phreodrilus subterraneous Beddard as unciliated but Benham (1904) noted the presence of cilia within the same, but less coiled, structure of Phreodrilus beddardi. Neither author reported cilia within the atrium (termed a diverticulum by them). Other species descriptions have not noted the presence of cilia in these organs, but examination of specimens of Phreodrilus branchiatus Beddard in the author's collection and the type material of Phreodrilus diemenensis Pinder and Brinkhurst revealed cilia in the coiled pseudopenis of these species, with ciliation also extending much further into the non-pseudopenial part of the atrium than in $P$. peniculus. Cilia are also present in the coiled pseudopenis and in the ental part of the ejaculatory duct of a new Phreodrilus from Oman (B. Sambugar pers. comm.). Ciliation could not be detected in the uncoiled pseudopenis and atrium of the single known specimens of Phreodrilus melaleucensis and Phreodrilus mitodes. The type (and only) specimens of the remaining member of this genus, Phreodrilus mauienensis, were not examined since they are known to be mounted in a medium that has obscured most of the internal anatomy. Species of other genera, including Insulodrilus lacustris, Insulodrilus bifidus, Antarctodrilus micros, Antarctodrilus proboscidea, Antarctodrilus horwitzi (all specimens in the author's collection) and the new Astacopsidrilus described below, were examined but these lacked ciliation in the atrium and ejaculatory duct.

Phreodrilus pseudopenes are thought (e.g. Brinkhurst 1965) to have arisen by separation of the muscle and lining tissues of the ectal part of the atrium, with subsequent elongation and coiling of the tube of lining tissue in some species. This seems to provide the inner tube with flexibility to match its muscular sac, allowing the whole structure to be protruded from the male pores (Beddard 1891; Brinkhurst 1965). Thus, an organ that is entirely glandular in most phreodrilid genera, has become partly modified as a sperm transport and copulatory organ in Phreodrilus. Ciliation of the pseudopenis may be an apomorphic trait associated with this modification, aiding the passage of sperm through the narrow duct, as in the vas deferens. Absence of ciliation in some Phreodrilus might indicate more than one lineage within the group, although $P$. subterraneous should be re-examined as it is undoubtedly closely related to congeners with 
highly coiled pseudopenes and it would be surprising if cilia were absent in the pseudopenes of this species.

\section{Astacopsidrilus edwardi sp. nov.} Figures $1 \mathrm{~B}$ and $2 \mathrm{~B}$

\section{Material examined}

\section{Holotype}

Temporary seepage on Merredin Rock, Merredin, $31^{\circ} 28^{\prime} \mathrm{S} 118^{\circ} 17^{\prime} \mathrm{E}, 5$ Jul 1996, coll. D. Edward, 1 dissected on slide (WAM V 4210).

\section{Paratypes}

Type locality and date, 4 mature on slides, 3 mature and 6 immature in alcohol (WAM V 4211 WAM V 4215) and 1 mature on slide (AP collection). Seepage on Boorabbin Rock, $95 \mathrm{~km}$ east of Southern Cross, $120^{\circ} 16^{\prime} \mathrm{S} 31^{\circ} 12^{\prime} \mathrm{E}, 5$ Jul 1996, 1 mature and 6 immature on slides, 1 mature and 10 immature in alcohol (WAM V 4221 - WAM V 4228). Seepage on Woorkabing Hill, about $20 \mathrm{~km}$ north of Wickepin, 32 $38^{\prime} 00^{\prime \prime} \mathrm{S} 117^{\circ} 26^{\prime} \mathrm{E}$, 11 Jun 1995, 3 mature and 1 immature on slides, 2 mature in alcohol (WAM V 4229 - WAM V 4233). All collected by D. Edward.

\section{Etymology}

Named in honour of the collector, Dr. Donald H.D. Edward (Zoology Department, The University of Western Australia).

\section{Description}

Length of preserved specimens $10-15 \mathrm{~mm}$. Width of $\times 0.4-0.5 \mathrm{~mm}$. Number of segments 46 to 69. Prostomium bluntly rounded. Pharynx in II III, pharyngeal glands on pharynx and septa 3/4$6 / 7$. Gut enlarging in $X$, most specimens with a thick layer of chlorogogue cells on gut and most septa. Ventral chaetae paired from II, mostly 95 $125 \mu \mathrm{m}$ long, longest in first few segments, both chaetae with rudimentary upper teeth and a distal nodulus (Figure 1B). Ventral chaetae of XIII (and often of XI and/or XIV) paired within enlarged glandular sacs, one of each pair long (107 - $192 \mathrm{um}$ ) with hollow distal half and sharp tip, projecting from the sac, and one shorter and mostly contained within the sac. Dorsal chaetae 1 or 2 short $(75-132$ $\mu \mathrm{m})$ thin hairs per bundle, each with a pair of support chaetae. Hairs hardly visible at low magnification.

Genitalia paired. Testes and ovaries in XI and XII respectively. Clitellum from $1 / 2$ XII to $12 / 13$. Male funnels cup-shaped on $11 / 12$, feeding ciliated vasa

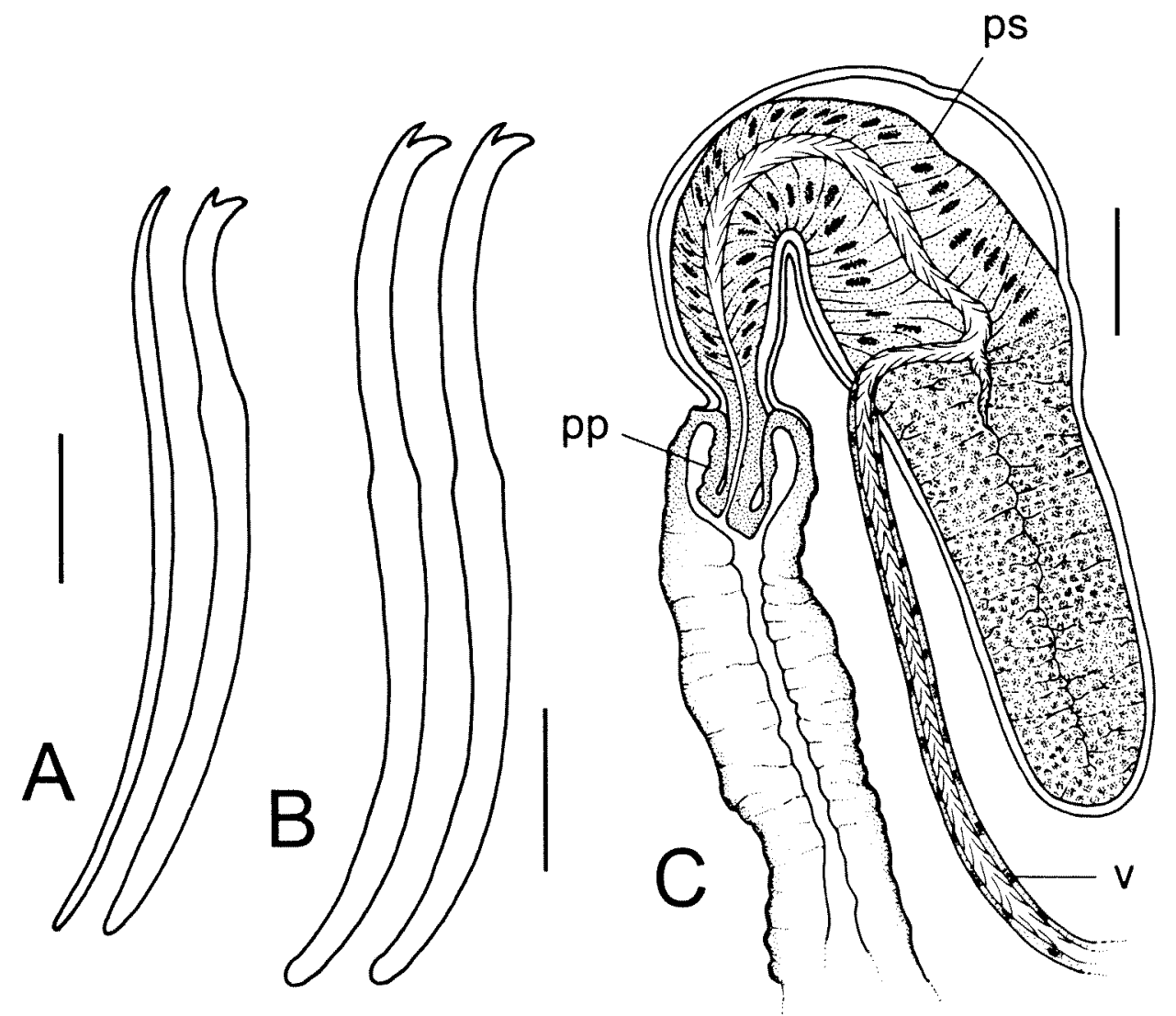

Figure 1 A, pair of ventral chaetae of Phreodrilus peniculus sp. nov.; B, pair of ventral chaetae of Astacopsidrilus edwardi sp. nov.; C, male genitalia of Phreodrilus peniculus sp. nov. paratype V4206. Scale lines: A and B, $20 \mu \mathrm{m} ; \mathrm{C}, 50$ $\mu \mathrm{m}$. pp, pendant penis; ps, pseudopenis; $v$, vas deferens. 

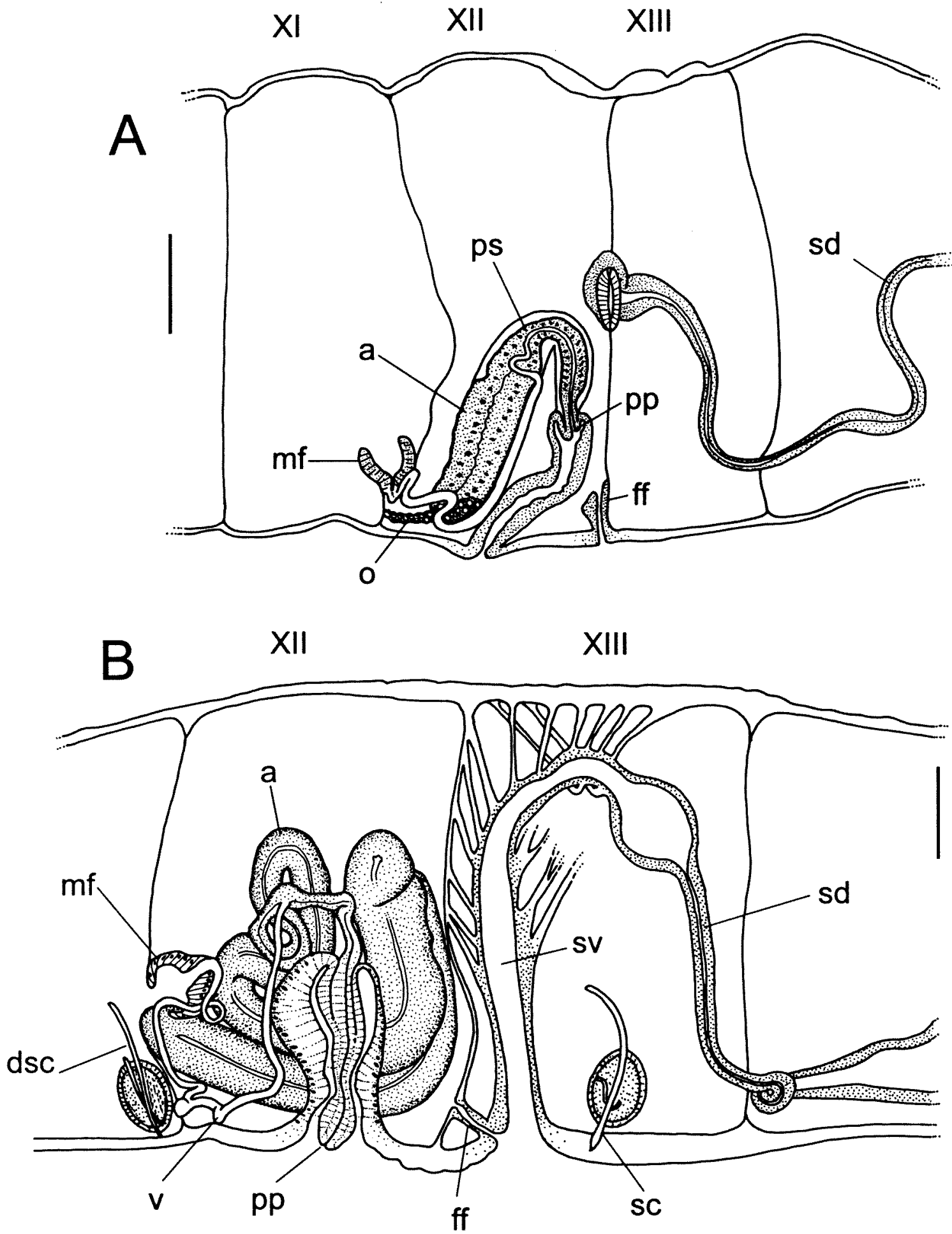

Figure 2 A, genitalia of Phreodrilus peniculus sp. nov. holotype; B, genitalia of Astacopidrilus edwardi sp. nov holotype. Scale lines: A and B, $100 \mu \mathrm{m}$. a, atrium; dsc. duplicate spermathecal chaeta; ff, female funnel; mf, male funnel; o, ovary; pp, pendant penis; ps, pseudopenis; sc, spermathecal chaeta; sd, spermathecal duct; sv, spermathecal vestibule; $v$, vas deferens.

deferentia. Convoluted atria long and moderately broad $(875 \times 125-1300 \times 112 \mu \mathrm{m})$ with narrow lumen, narrowing to form ejaculatory ducts (width $15-20 \mu \mathrm{m})$ after union with the vasa deferentia (Figure 2B). Pendant penes well developed, within penis sacs which open ventro-laterally mid-way between $11 / 12$ and $12 / 13$. Spermathecal vestibules tall and muscular with ventro-lateral openings on anterior of XIII (Figure 2B). Vestibules with muscular attachments to dorso-lateral and dorsal body wall and septa $12 / 13$, giving rise to spermathecal ducts each with a swelling ectally 
(Figure 2B). Spermathecal vestibules and ducts (and possibly the ampullae) replicated in XIV in one specimen. Spermathecal ampullae, with loose sperm in mated individuals, extending from XIV to as far posteriad as XVIII. Female funnels ventrolateral on $12 / 13$ leading to pores within spermathecal vestibules (Figure $2 \mathrm{~B}$ ).

\section{Remarks.}

The tall muscular spermathecal vestibules incorporating the female pores are characteristic of species of the genus Astacopsidrilus. Of its congeners, the new species is most similar to Astacopsidrilus ostiensis Pinder and Erséus, 2000, an estuarine species from Tasmania and Astacopsidrilus beckettae Pinder and Brinkhurst, 1997, from streams on subantarctic Campbell Island. It is distinguished from both of these by the swelling on the spermathecal ducts. In addition, $A$. beckettae has narrower atria $(<30 \mu \mathrm{m})$, lacks the narrow ejaculatory ducts and has smaller chaetae, while $A$. ostiensis has much larger penes and broader spermathecal vestibules.

\section{Insulodrilus bifidus Pinder and Brinkhurst}

Insulodrilus bifidus Pinder and Brinkhurst, 1997, 491, Figures 109-112.

\section{Material examined}

This species has been identified from numerous additional localities in the vicinity of those listed by Pinder and Brinkhurst (1997) (Walpole to Lake Muir region) but also the following sites which represent range extensions. Various streams near Pemberton (such as Carey Brook and Treen Brook) sampled by the author and $\mathrm{K}$. Trayler, confirming the tentative identification from this region in Pinder and Brinkhurst (1997); Lake Jasper, $34^{\circ} 25^{\prime} 16^{\prime \prime} \mathrm{S} 115^{\circ} 41^{\prime} 29^{\prime \prime} \mathrm{E}, 14$ Sep 1996, coll. A. Pinder and R.O. Brinkhurst; Helena River, 31 $56^{\circ} 37^{\prime \prime} \mathrm{S}$ 116 26'11"E, 29 Oct 1997; Lake Pleasant View, $34^{\circ} 49^{\prime} 51^{\prime \prime} \mathrm{S} 118^{\circ} 10^{\prime} 59^{\prime \prime} \mathrm{E} 29$ Sep 1998; Qualeup Lake, 33 $50^{\prime} 19^{\prime \prime S} 116^{\circ} 45^{\prime} 52^{\prime \prime} \mathrm{E}, 9$ Oct 1998; Nalyerin Lake, 33008'51"S 116 $22^{\circ} 15^{\prime \prime} \mathrm{E}, 8$ Oct 1998; Ngopitchup

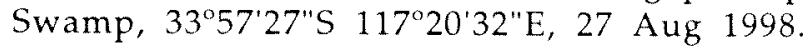
Specimens from the latter sites all collected by A.M. Pinder and J.M. McRae and retained by the author.

\section{Remarks}

This species is readily identified by its single bifid chaeta per dorsal bundle, instead of the usual hair chaetae. It is the most common phreodrilid in the higher rainfall south-west, extending north to at least the Helena River and is the only phreodrilid known from wetlands in the south-west (other than habitats on granite outcrops) in areas with rainfall less than $800 \mathrm{~mm}$.

\section{Antarctodrilus micros Pinder and Brinkhurst}

Antarctodrilus micros Pinder and Brinkhurst, 1997, 467, Figures $45-47$

\section{Material examined}

Lake Smith, $34^{\circ} 25^{\prime} 52^{\prime \prime S} 115^{\circ} 07^{\prime} 52^{\prime \prime} \mathrm{E}, 14$ Sep 1996, 3 mature on slide, several in alcohol, coll. A. Pinder and R.O. Brinkhurst (AP collection). Twilight Cave, 3133'53"S 11541'25"E, 27 Aug 1994, Yanchep National Park, 3 mature on slides, coll. E.J. Jasinska (AP collection). Carpark Cave, 31 $33^{\prime} 11^{\prime \prime} \mathrm{S}$ $115^{\circ} 40^{\prime} 54^{\prime \prime} \mathrm{E}, 31$ Nov 1996, Yanchep National Park, 1 on slide, coll. E.J. Jasinska (AP collection). Kudjal

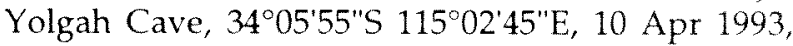
Leeuwin-Naturalist Caves, 3 mature on slide, coll. E.J. Jasinska (AP collection).

\section{Remarks}

The new specimens conform to the original description, except for the slightly larger atria (up to $200 \times 56 \mu \mathrm{m}$ ) than those described for the holotype $(160 \times 47 \mu \mathrm{m})$. However, there is some variation in the length of this organ in most phreodrilids. As for the type specimens, the genital organs are shifted forwards by several segments compared to their normal position for the family (segments XII and XIII). On one specimen male and spermathecal pores are on $\mathrm{V}$ and $\mathrm{VI}$ respectively. An examination of the new and type material suggests that the muscle and lining tissue are separate between the vas deferens/atrial union and the penis, but, considering the very small size of this area, I am reluctant to conclude that this is homologous with the pseudopenes of Phreodrilis at this stage. All Phreodrilus described so far have the ventral chaetae of a pair dissimilar (i.e. one bifid and one simple-pointed) whereas $A$. micros has both chaetae of a pair bifid, as in many other members of the probably paraphyletic Antarctodrilus.

Antarctodrilus micros is known from surface and cave waters of the Warren bioregion and from streams in a number of caves just north of Perth. The latter represent a significant range extension for this species.

\section{Antarctodrilus horwitzi Pinder and Brinkhurst}

Antarctodrilus horwitzi Pinder and Brinkhurst, 1997, 469, Figures 48-51.

\section{Material examined}

Tributary of Deep River on eastern portion of Meredith Road, 34 58'54'S 116 37'47"E, 8 Sep 1996 , 1 on slide; Carey Brook at Pile Road crossing, $34^{\circ} 21^{\prime} 29^{\prime \prime S} 115^{\circ} 54^{\prime} 29^{\prime \prime} \mathrm{E}, 16$ Sep 1996, 2 on slides; Collier Creek on road running east of Cemetary Road, $34^{\circ} 58^{\prime} 30^{\prime \prime} S 116^{\circ} 46^{\prime} 00^{\prime \prime} \mathrm{E}, 11$ Sep 1996, 2 on slides; Upper tributary of Beedelup Brook South, 
$34^{\circ} 22^{\prime} 18^{\prime \prime} \mathrm{S} 115^{\circ} 56^{\prime} 15^{\prime \prime} \mathrm{E}, 16$ Sep 1996,1 on slide. All collected by A. Pinder and R.O. Brinkhurst.

\section{Remarks}

The original description of $A$. horwitzi was based on the single type specimen, each atrium of which has a broad sperm-filled lumen for its entire length. By contrast, the new specimens have thick atrial lining tissue with a narrow lumen, although the ental extremity of the atrium has a broad sperm filled lumen and thinner lining tissue in some specimens. These differences in atrial histology may represent different stages in the reproductive cycle. The new specimens otherwise closely resemble the holotype. Their atria are of a similar shape but slightly smaller size ( $378 \pm 55 \mu \mathrm{m} \times 55 \pm 5 \mu \mathrm{m}, \mathrm{n}=4$, compared to $500 \times 75 \mu \mathrm{m}$ in the holotype). Considering that the new specimens are incomplete, their original length $(>6 \mathrm{~mm})$ is probably not dissimilar to the holotype $(9.8 \mathrm{~mm})$ and the number and form of the chaetae also agree with the holotype. The new specimens have pre-clitellar ventral chaetae 113 to $122 \mathrm{um}$ long, compared to 112 to 138 um on the holotype. The ventral chaetae of the holotype were wrongly measured as 77 to 108 um in Pinder and Brinkhurst (1997). There is still no indication of where the vasa deferentia join the atria.

This species has been collected only in the Warren bioregion of south-western Australia. The new records confirm that this species occurs at least as far west as the Pemberton area, as supposed from immature specimens by Pinder and Brinkhurst (1997).

\section{Phreodrilid WA3}

Phreodrilid WA3 is one of the undescribed species listed by Pinder and Brinkhurst (1997). This distinctive worm (with up to 50 short hairs per dorsal bundle posteriorly, Figure 166 op. cit.) is common in the Warren region but has now also been recorded from Lesmurdie Falls near Perth. Unfortunately, specimens that are both mature and complete (i.e. with the distinctive tail end) have not yet been collected.

\section{DISCUSSION}

Although the far south-west of Western Australia still appears to be an area of particularly high phreodrilid diversity, comparable only to Tasmania in the number of species and level of endemism (Pinder 2001), the new species show that the family is certainly not restricted to this region and suggest there may be considerable diversity in suitable microhabitats further inland and north.

Phreodrilus peniculus is the first phreodrilid to be described from northern Australia and is one of the undescribed species noted from north-western Australia by Pinder (2001). Thus far, all northern Australian surface waters from which phreodrilids have been found have been reaches of seasonal rivers which have cobble/gravel sediments and/or receive water from perennial springs. This suggests a hyporheic/groundwater association, although oligochaetes have not been well surveyed in other habitats in the region. Immature phreodrilids have been collected from groundwater in the north-west and interior of Western Australia by Dr William Humphries (Western Australian Museum) and Dr Brenton Knott (The University of Western Australia). Other groundwater phreodrilids have been described from North Africa (Giani et al., 1995) and New Zealand (Benham, 1904), and phreodrilids have been recovered from groundwater in the Middle-East (B. Sambugar, pers. comm.).

Granite outcrops are another habitat where phreodrilids are turning out to be especially diverse. Astacopsidrilus edwardi is one of five new phreodrilid species recorded on granite outcrops in southern Western Australia (Pinder, 2001; Pinder $e t$ al., 2000), most of which were collected by Dr. Donald Edward. Unfortunately, there is insufficient material to describe the other species. So far, the five species are known from just 10 outcrops, with each outcrop having only 1 species. All specimens of $A$. edwardi were collected from seepages arising from herbaceous meadows on granite outcrops. These seepages are temporary habitats, occurring for periods of days to months depending on the season and amount of recent rainfall and both the seepages and herbaceous meadows are completely dry for many months each year. This seems an extreme habitat for aquatic oligochaetes, particularly for phreodrilids which normally occur in habitats with at least some perennial moisture. The three localities listed for $A$. edwardi are all in inland areas with average annual rainfall between 275 and $450 \mathrm{~mm}$ and one of the undescribed outcrop species occurs in an area with rainfall less than $200 \mathrm{~mm}$. By contrast, the several phreodrilid species occupying other types of surface waters in the south-west appear to be restricted to the more coastal areas with rainfall 500 to $1400 \mathrm{~mm}$, with all but one of these (Insulodrilus bifidus Pinder and Brinkhurst, 1997) known only from areas with rainfall greater than $800 \mathrm{~mm}$ (Pinder, 2001). Evidence for the lack of phreodrilids in other types of wetlands in lower rainfall areas of the south-west comes from an extensive (but as yet unpublished) survey of invertebrates from a wide variety of wetland types in the wheatbelt (most of which are seasonally dry), being carried out by the Department of Conservation and Land Management. Thus, granite outcrops appear to be islands of phreodrilid diversity in the drier inland south-west. The reasons for this are not clear. One 
consideration is that granite outcrops are largely impervious substrates and thus retain fresh surface moisture more readily than other aquatic habitats following rainfall events. Bayly (1997) and Pinder et al. (2000) discuss the diversity and uniqueness of invertebrate assemblages occupying aquatic habitats on these outcrops. Most of these other invertebrates occupy pools rather than seepages, with the significant exception of the chironomid genus Archaeochlus, which, like the phreodrilids, appears to have a global distribution indicative of a Gondwanan origin (Cranston et al., 1987; Edward, 1989). Both these and the phreodrilids may have preferentially survived on granite outcrops as the south-west became increasingly arid from the midTertiary. The ability of the granite outcrop worms to survive dry periods has not been investigated but presumably involves desiccation resistant cocoons.

\section{ACKNOWLEDGEMENTS}

Specimens of previously described material were made available by Kerry Trayler or Edyta Jasinska or were collected by the author during an Australian Biological Resources Study grant to R. Marchant (Museum of Victoria) or during a biological survey of the wheatbelt (part of the State Salinity Strategy). Specimens of $P$. peniculus were collected during the Monitoring of River Health Initiative and a survey of invertebrates from Pilbara springs and were made available by Stuart Halse (Department of Conservation and Land Management). Specimens of $A$. edwardi were provided by Don Edward (The University of Western Australia). Beatrice Sambugar kindly provided previews of descriptions of new phreodrilids from Oman. Christer Erseus and Tarmo Timm provided useful comments on an earlier version of this paper and Lena Gustavsson and Ralph Brinkhurst engaged in useful discussion about the genitalia of Phreodrilus. Ralph Brinkhurst, Jane McRae and Lynette Pitman assisted in the field.

\section{REFERENCES}

Bayly, I.A.E. (1997). Invertebrates of temporary waters in gnammas on granite outcrops in Western Australia. Journal of the Royal Society of Western Australia 80: 167172.

Beddard, F.E. (1891). Anatomical description of two new genera of aquatic Oligochaeta. Transactions of the Royal Society of Edinburgh 36: 273-303.

Benham, W.B. (1904). On some new species of the genus Phreodrilus. Quarterly Journal of Microscopical Science 48: 271-298.

Brinkhurst, R.O. (1965). A taxonomic revision of the Phreodrilidae (Oligochaeta). Journal of Zoology 147: 363-386.

Brinkhurst, R.O. (1991). A phylogenetic analysis of the Phreodrilidae (Annelida, Oligochaeta), with a description of a new species. Canadian Journal of Zoology 69: 2031-2040.

Cranston, P.S., Edward, D.H.D. and Colless, D.H. (1987). Archeochlus Brundin: a midge out of time (Diptera: Chironomidae). Systematic Entomology 12: 313 - 334.

Edward, D.H.D. (1989). Gondwanaland elements in the Chironomidae (Diptera) of south-western Australia. Acta Biologica Debrechina Oecologica Hungarica 2: 181187.

Giani, N., Martin, P. and Juget, J. (1995). A new species of Phreodrilidae (Oligochaeta), Astacopsidrilus naceri sp. nov., from Morocco (North Africa), with notes on the biogeography of the family. Canadian Journal of Zoology 73: 2375-2381.

Halse, S.A., Scanlon, M.D. and Cocking, J.S. (2002). Do springs provide a window to the groundwater fauna of the Australian arid zone? In, Balancing the Groundwater Budget: Proceedings of an International Groundwater Conference, Darwin, 2002. International Association of Hydrogeologists (Available on CD).

Jackson, A. (1931). The Oligochaeta of South-Western Australia. Journal of the Royal Society of Western Australia 17: 71-136.

Pinder, A.M. (2001). Notes on the diversity and distribution of Australian Naididae and Phreodrilidae (Oligochaeta: Annelida). Hydrobiologia 463: 49-64.

Pinder, A.M. and Brinkhurst, R.O. (1997). A review of the Phreodrilidae (Annelida: Oligochaeta: Tubificida) of Australia. Invertebrate Taxonomy 11: 443-523.

Pinder, A.M. and Erseus, C. (2000). New Phreodrilidae (Annelida: Clitellata) from Tasmanian Estuaries. Papers and Proceedings of the Royal Society of Tasmania 134: 29-33.

Pinder, A.M., Halse, S.A., Shiel, R.J. and McRae, J.M. (2000). Granite outcrop pools in south-western Australia: foci of diversification and refugia for aquatic invertebrates. Journal of the Royal Society of Western Australia 83: 149-161. 